\title{
$\bullet \cdot$ \\ IJCRR \\ Study on Blood Donation Among Medical Students of Udaipur City, Rajasthan
}

Section: Healthcare

Sci. Journal Impact

Factor: 5.385 (2017)

ICv: 71.54 (2015) Shiv Lal Solanki ${ }^{1}$, Abhilasha Mali²

'Principal, PDU Medical College, Churu (Rajasthan), India; ${ }^{2}$ Statistician Tutor, Department of Community Medicine, American International Institute of Medical Sciences, Udaipur (Rajasthan), India

\section{ABSTRACT}

Background: This study has been carried out to know the knowledge, attitude and behavior about blood donation among medical college students of Udaipur city. Human blood is an essential element of life and it cannot be substituted other than human blood. Blood is needed crucially for transfusion in multiple diseases, episodes of injuries and the only source of blood is donation.

Methods: This cross- sectional study was conducted in Udaipur city of Rajasthan on medical college students, to explore their knowledge, attitude and practice on blood donation. Sample of 150 respondents was studied, during the period of October 2016December 2016.

Results: Majority of respondents was aware, and had the good knowledge on blood donation. Blood group "O" is a universal donor is also known to majority of the subjects. The minimum age to donate blood was known to majority of the respondents and most of them were willing to donate blood with a view that the blood donation is useful and beneficial to society. Very few of the study subjects have ever donated blood and the frequency of blood donation was observed more in male donors than female. Majority of the donor's preferred to donate blood to their relatives.

Conclusions: This study reveals that having good knowledge on blood donation, less number of respondents had ever donated the blood. Major steps should be initiated to overcome the obstacles with provision of adequate literature, advertisements and communication material for enhancing positive attitude of medical college students so that they start to take part willingly in voluntary blood donation. A good positive attitude may lead to higher eagerness for blood donation. .

Key Words: Voluntary, Awareness, Emergency, Relatives, Human life

\section{INTRODUCTION}

Blood is a very specialized body fluid of humans which deliver necessary substances such as nutrients and oxygen to the cells and help in transportation of metabolic waste products away from the cells ${ }^{1}$.

Blood is manufactured by human beings and donation of blood by humans is the only way of acquiring blood to meet emergency requirements in cases of road traffic accidents, complications of pregnancy like ant partum and post partum hemorrhage, blood loss during childbirth, various anemic disorders and surgical emergencies ${ }^{2}$.

According to world health organization, an estimated $38 \%$ of reported voluntary blood donations are contributed by people under the age of twenty five. World health organiza- tion also insists the developing and developed countries, to focus on young people, to achieve hundred per cent voluntary unpaid blood donation ${ }^{3}$. India needs about 7 million units of blood annually and every year there is gradual increase in this demand ${ }^{4}$ due to various anemic disorders, accidents and emergencies. Millions of lives are saved each year in the globe, through blood transfusions, but the percentage of voluntary unpaid donors and the safety of blood transfusion is still a concern, particularly in the developing countries 5 .

It is estimated that donation by $1 \%$ of the population is sufficient to meet a nation's most basic requirements for blood $^{5}$. The World health organization recommends that the blood which is to be donated should be tested for some important infections like HIV, Hepatitis B, Hepatitis C,

\section{Corresponding Author:}

Dr. Shiv Lal Solanki, MBBS, MD (PSM), Principal, PDU Medical College, Churu (Rajasthan), India

Mobile no +91 9829228403; E-mail: solankisl@yahoo.co.in

ISSN: 2231-2196 (Print)

Received: 30.06 .2018
ISSN: 0975-5241 (Online)

Revised: 23.07.2018
Accepted: 11.08 .2018 
Syphilis, Malaria as these infections can be transmitted by blood donation to the recipients ${ }^{6}$.

Blood services are facing shortage of blood all over the world. Demand of blood is rising day by day and the current blood donation is insufficient to meet the demand. The WHO has categorized India as having less than 10 blood donations per 1000 population, with voluntary collection of 50\%--89\% of the total blood collection.

The medical students were aimed at for conducting our study because they represent the potential blood donors among the young population pool of tomorrow for our nation.

\section{OBJECTIVES}

To know the knowledge, attitude and behavior towards blood donation among medical college students.

\section{MATERIALS AND METHODS}

This cross sectional study was conducted on 150 first MBBS students of Geetanjali Medical College and Hospital, Udaipur, during October 2016 to December 2016. Information regarding knowledge, attitude and practice for blood donation was recorded in a pre tested proforma, after obtaining the written consent from study subjects. Data was analyzed and results were expressed as using proportional percentage.

\section{RESULTS}

Table 1: Age wise distribution of study subjects $(\mathbf{n}=\mathbf{1 5 0})$.

\begin{tabular}{llrlrlr} 
Age (Years) & \multicolumn{1}{l}{ Male $\%$} & \multicolumn{2}{c}{ Female $\%$} & No. & \multicolumn{1}{c}{$\%$} \\
$17-18$ & 2 & $(1.33 \%)$ & 4 & $(2.66 \%)$ & 6 & $(3.99 \%)$ \\
$18-19$ & 40 & $(26.67 \%)$ & 40 & $(26.67 \%)$ & 80 & $(53.34 \%)$ \\
$19-20$ & 23 & $(15.33 \%)$ & 25 & $(16.67 \%)$ & 48 & $(32.0 \%)$ \\
$20-21$ & 10 & $(6.67 \%)$ & 6 & $(4.00 \%)$ & 16 & $(10.67 \%)$ \\
Total & 75 & $(50 \%)$ & 75 & $(50 \%)$ & 150 & $(100 \%)$ \\
\hline
\end{tabular}

The study sample consisted of (50\%) males and (50\%) females.

The study participants included age range of 17-21 years. (53.34\%) of study participants belonged to $18-19$ years age group followed by $(32.0 \%)$ in age group $19-20$ years. Minimum participants $(3.99 \%)$ were of $17-18$ years of age. The mean age of students was $18.95 \pm 0.71$ S.D. Years.
Table 2: Knowledge regarding essentials for blood donation among study subjects $(n=150)$.

\begin{tabular}{|c|c|c|}
\hline $\begin{array}{l}\text { * Correct knowledge regarding blood } \\
\text { donation }\end{array}$ & No. & $\%$ \\
\hline Which blood group is universal donor? & 117 & $(78 \%)$ \\
\hline Which blood group is universal recipient? & 114 & $(76 \%)$ \\
\hline Types of blood groups are? & 147 & $(98 \%)$ \\
\hline Do you know your blood group? & 129 & $(86 \%)$ \\
\hline $\begin{array}{l}\text { What is the minimum weight to donate } \\
\text { blood of donor? }\end{array}$ & 120 & $(80 \%)$ \\
\hline $\begin{array}{l}\text { What is the maximum age to donate blood } \\
\text { of donor? }\end{array}$ & 127 & $(84.66 \%)$ \\
\hline $\begin{array}{l}\text { How much ml. blood volume is collected in } \\
\text { one donation? }\end{array}$ & 50 & $(33 \cdot 33 \%)$ \\
\hline $\begin{array}{l}\text { Can blood be collected without being tested } \\
\text { for certain diseases? }\end{array}$ & 150 & $(100 \%)$ \\
\hline $\begin{array}{l}\text { At what duration blood can be donated, if } \\
\text { donated once? }\end{array}$ & 123 & $(82 \%)$ \\
\hline
\end{tabular}

* Multiple responses, total not additive.

$(78.0 \%)$ of the study subject knew that the blood group "O" is universal donor, (76.\%) knew about the blood group "AB" is universal recipient. Majority (98\%) knew, regarding 4 types of blood groups and $(86 \%)$ knew for their own blood group. (80\%) of the subjects knew that the $45 \mathrm{~kg}$ is minimum weight to donate blood, and $(84.66 \%)$ were know that the 60 year of age is maximum age to donate the blood, (82\%) were know after 90 days blood can be donated if donated once, $(33.33 \%)$ of the subjects have the knowledge about $350 \mathrm{ml}$ of blood volume is collected in one spell of donation and all (100\%) subject were know that blood of the donor, must be tested for HIV, Hepatitis B, Hepatitis C, Syphilis, Malaria before blood collection.

Table 3: Distribution of study subjects according attitude toward blood donation.

\begin{tabular}{|c|c|c|}
\hline $\begin{array}{l}\text { Attitude towards blood } \\
\text { donation }\end{array}$ & $\begin{array}{l}\text { Responses of } \\
\text { study subjects }\end{array}$ & No. $\%$ \\
\hline $\begin{array}{l}\text { Do you willing to donate } \\
\text { blood? }(n=150)\end{array}$ & $\begin{array}{l}\text { Yes } \\
\text { No } \\
\text { Total }\end{array}$ & $\begin{array}{ll}144 & (96 \%) \\
06 & (4 \%) \\
150 & (100 \%)\end{array}$ \\
\hline $\begin{array}{l}\text { Do you believe that blood } \\
\text { donation is beneficial to } \\
\text { society? }(n=150)\end{array}$ & $\begin{array}{l}\text { Yes } \\
\text { No } \\
\text { Total }\end{array}$ & $\begin{array}{ll}147 & (98 \%) \\
03 & (2 \%) \\
150 & (100 \%)\end{array}$ \\
\hline $\begin{array}{l}\text { Do you always take permis- } \\
\text { sion before blood donation? } \\
(n=150)\end{array}$ & $\begin{array}{l}\text { Yes } \\
\text { No } \\
\text { Total }\end{array}$ & $\begin{array}{ll}50 & (33 \cdot 33 \%) \\
100 & (66.67 \%) \\
150 & (100 \%)\end{array}$ \\
\hline $\begin{array}{l}\text { Do you want to voluntary } \\
\text { unpaid blood donor? } \\
(n=150)\end{array}$ & $\begin{array}{l}\text { Yes } \\
\text { No } \\
\text { Total }\end{array}$ & $\begin{array}{lc}143 & (95 \cdot 33 \%) \\
7 & (4.67 \%) \\
150 & (100 \%)\end{array}$ \\
\hline $\begin{array}{l}\text { Do you encourage people to } \\
\text { donate blood? }(\mathrm{n}=150)\end{array}$ & $\begin{array}{l}\text { Yes } \\
\text { No } \\
\text { Total }\end{array}$ & $\begin{array}{ll}150 & (100 \%) \\
0 & (0 \%) \\
150 & (100 \%) \\
\end{array}$ \\
\hline
\end{tabular}


Out of 150 study subjects, (96\%) were willing to donate the blood, (98\%) of the subjects believed that blood donation is beneficial to society. (66.67\%) of the study participants had the opinion to take permission from elderly before blood donation. $(95.33 \%)$ of study participants want to become voluntary unpaid donor. All 150 study participants encouraged the people for blood donation.

Table 4: Distribution of study subjects according to behavior about blood donation.

\begin{tabular}{llll}
$\begin{array}{l}\text { Behavior towards } \\
\text { blood donation }\end{array}$ & Responses & No. & $\%$ \\
\hline $\begin{array}{l}\text { Ever donated blood } \\
(\mathrm{N}=150)\end{array}$ & Yes & 21 & $(14 \%)$ \\
& No & 129 & $(86 \%)$ \\
Ever donated blood, & Total & 150 & $(100 \%)$ \\
gender wise (N=21) & Fale & 17 & $(80.95 \%)$ \\
& Female & 04 & $(19.04 \%)$ \\
Ever donated blood, if & Voluntary & 21 & $(100 \%)$ \\
asked (n=21) & Non - voluntary & o & $(100 \%)$ \\
& Total & 21 & $(100 \%)$ \\
Blood donated to whom & Friends & 06 & $(28.57 \%)$ \\
$(\mathrm{n}=21)$ & Relatives & 14 & $(66.67 \%)$ \\
& Unknown per- & 01 & $(4.76 \%)$ \\
& sons & 21 & $(100 \%)$ \\
& Total & & \\
\hline
\end{tabular}

Out of 150 study subjects only (14\%) ever donated blood. Out of 21 who ever donated blood $(80.95 \%)$ were male against $(19.4 \%)$ female. (100\%) of the subjects donated blood voluntarily and majority $(66.67 \%)$ of donors donated blood to their relatives.

Table 5: Distribution of study subjects for reasons for not donating blood $(n=129)$.

\begin{tabular}{|c|c|}
\hline $\begin{array}{l}\text { Reasons for not donating blood among } \\
\text { Non- donor Students }\end{array}$ & No. \% \\
\hline No support from family & $12 \quad(9.31 \%)$ \\
\hline Afraid of procedure & $61 \quad(47.29 \%)$ \\
\hline Fear of Weakness & o6 (4.65\%) \\
\hline Fear of contracting any disease & $06 \quad(4.65 \%)$ \\
\hline Why to Donate to Unknown & $04 \quad(3.10 \%)$ \\
\hline No one asked them & $40 \quad(31.00 \%)$ \\
\hline Total & $129(100 \%)$ \\
\hline
\end{tabular}

In the present study the cause of not to ever donate blood in majority was afraid of procedure (47.29\%) followed by $(31.0 \%)$ no one asked them, $(9.31 \%)$ not supported by family and only $(3.10 \%)$ were of the opinion that there is no need to donate blood to unknown persons.

\section{DISCUSSION}

The 150 study participants, included age range of 17-21 years. $(80 \%)$ of students had knowledge regarding the minimum necessary body weight for blood donation ie $45 \mathrm{~kg}$. Similar findings ( $72 \%$ ) were observed by Giri PA et $\mathrm{al}^{7}$. Majority $(84.66 \%)$ of study subjects were aware of the appropriate age for blood donation ie 18 years to 60 years. The appropriate age was known to (92\%) of the study subjects in study by Giri PA et al ${ }^{7}$ while less values $(11.7 \%)$ were observed by Hossein S. et $\mathrm{al}^{8}$. Shahshahani HJ et $\mathrm{al}^{9}$ found in their study in Iran that less than $50 \%$ of the respondents were aware about the minimum age for blood donation.

$(14 \%)$ of study subjects in our study, did not know their own blood group. This was similar to $(18.18 \%)$ the findings of study conducted by Arun et $\mathrm{a}^{10}$. Majority (96\%) of study subjects showed positive attitude towards blood donation, against the values observed in various studies, by Hossain GM et. al. ${ }^{11}$ (82\%), S Manikandan et al ${ }^{12}(63.58 \%)$, Abhishek et $\mathrm{al}^{13}(93.77 \%)$ and Shenga $\mathrm{N}$ et $\mathrm{al}{ }^{14}(87.23 \%)$. In present study majority (98\%) of the participants viewed that the blood donation is beneficial to society, similar to finding by Arun et. $\mathrm{al}^{10}(97.6 \%)$. Majority ( $\left.86 \%\right)$ of study subjects have not donated blood ever, similar findings were observed $(87.3 \%)$ and $(75.4 \%)$ by Shenga N et. al. ${ }^{14}$ and Hossain S et. $\mathrm{al}^{8}$ respectively. In study among married women homemakers conducted at Tehran by Khadir M et.a ${ }^{15}$ showed that (24.1\%) had ever donated blood and in another study in Palestinina central bureau of statistic ${ }^{16}$ revealed only $(20 \%)$ had ever donated blood but in our study this data is low (14\%) compared to others.

Among the donors in our study, majority of them were males $(80.95 \%)$ against females (19.05\%). Similar findings were observed by Shailesh K Mishra et al ${ }^{17}(75.8 \%)$ and $(24.2 \%)$ on 1000 college going students at Chandigarh, while Hossain $\mathrm{S}$ et $\mathrm{al}^{8}$ observed $(33.33 \%)$ male donors to $(18.7 \%)$ females donors.

In our study the common cause for not to donate the blood was fear of procedure $\left(47.29 \%\right.$ ), while Arun et $\mathrm{a}^{10}$ observed (31.34\%), S. Manikandan et $\mathrm{al}^{12}$ in their study of Chennai, observed only (27.4\%) while low figures $(9.75 \%)$ were observed by Abhishek et a $\mathrm{l}^{13}$.

No one asked to donate the blood for the cause (31\%), was observed in our study, similar to S Manikandan ${ }^{12}(32.21 \%)$, and Arun et $\mathrm{a}^{10}(26.12 \%)$, where as Shailesh K Mishra ${ }^{17}$ observed only (9.8\%), and Abhishek et al ${ }^{13}$ observed (42.68\%)

The cause due to fear of weakness for not to donate the blood was observed by S. Manikandan et al ${ }^{12}$ (12.61\%) and Shailesh K Mishra et $\mathrm{al}^{17}(19.0 \%)$ respectively against our findings $(4.65 \%)$.

In our study $(4.65 \%)$ of the respondents did not donate the 
blood due to fear of contracting any disease, this finding is supported by the study of Shailesh K Mishra et al ${ }^{17}(4.6 \%)$.

No one asked them was the reason observed among (31\%) of the respondents in our study, similar to the stusy by S Manikandan et al $^{12}(32.21 \%)$, while Shailesh K Mishra ${ }^{17}$ observed only $(9.8 \%)$.

No support from the family, the cause of not to donate the blood was $(9.31 \%)$ in our study while Abhishek et al ${ }^{13}$ observed $(14.6 \%)$.

\section{CONCLUSION}

It is evident by our study that greater knowledge about blood donation does not lead to high frequency of blood donation by medical college students. Special campaign is to be conducted to convert in to the actual blood donation by the medical students. If the medical college students set an example of blood donation on the eve of world donation day, that will in turn motivate and boost the morale of the community people for saving the human lives by donating blood. Voluntary blood donation by medical students with provision of adequate communication materials to masses, more advertisements to address the fears related to blood donation, shall increase the awareness among general masses in the society and it will also enhance the morals of voluntary blood donors to donate blood on regular basis to meet the challenges of blood transfusion of needy people.

\section{ACKNOWLEDGEMENTS}

Authors acknowledge the immense help received from the scholars whose articles are cited and included in references of this manuscript. The authors are also grateful to authors / editors / publishers of all those articles, journals and books from where the literature for this article has been reviewed and discussed.

Funding: No funding sources

Conflict of interest: None declared

Ethical approval: The study was approved by the institute ethics committee

\section{REFERENCES}

1. The franklin Institute Incorporatin (2014) "Blood" The Human Heart http://www.fi.edu/learrn/heart/blood.blood.html
2. World Health Organization. Global database on blood safely: report 01-2002. Available, from: http:// www. Who .int. / blood safely / GDBS. Report 2001-2002 pdf. [Last cited on 2010, Jan 31]

3. World Health Organization. (WHO), Blood Transfusion Safety. Available from: http://www.who.int/bloodsafety/volintary_donation/en/.

4. National AIDS control Organization (NACO), India. Voluntary blood donation programme - An operational Guideline, 2007, Available from: http://www/nacoonline.org/upload/ policies\&Guidelines/29, voluntary blood. donation.pdf

5. Dhingra N. World blood donor day: new blood for the world. World Health Organization.http://www.who.int/mediacenetre/ news/releasese/2010/blood_door_day_20100613/en

6. World Health Organization (2009) Screening Donated Blood for transfusing transmissible Infections. WHO, Geneva.

7. Giri PA, Palke DB. Knowledge and attitude about blood donation amongst undergraduate students of Pravara Institute of Medical Sciences Deemed University of Central India. Ann Trop Med public Health 2012:5:569-73-14

8. Hossein S, Nasim P, Batool M. University student's awareness and attitude towards blood donation in Kerman city. Iran J Blood Cancer 2009:1:3:107-10.

9. Shahshahani HJ, Yavari MT, Attar M, Ahmadiyeh MH, Knowledge, attitude and practice study about blood donation in the urban population of Yazd, Iran,2004. Transfusion Medicine. 2006/16:403-9

10. Arun Pulikkottil Jose et al, Knowledge, Attitude and practices on voluntary blood donation among college students in Bilaspur, Karnataka. Int J Cur Res Rev, June 2013/ Vol 05 (12) page 26.

11. Hossain GM, Anisuzzaman M, Begun A. Knowledge and attitude towards voluntary blood donation among Dhaka University students in Bangladesh East Afr Med J. 1997 Sep:74(9):549553.

12. S Manikanandan, R Srikumar, P N Ruvanthika. A study on knowledge attitude, and practice on blood donation among health professional students in Chennai, Tamil Nadu, South India. Int. J. of Scientific \& Research Publications:2013:3(3):1-4.

13. Abhishek Bachhotiya, V K Arora, Piyusha Mahashbde, Evaluation of intervention on voluntary blood donation among $1^{\text {st }}$ prof medical and dental students of index medical college. Indore (MP), India National Journal of Community Medicine Volume 5 , issue2,Apr- June2014

14. Shenga N, Pal R, Sengupta S, Pal S. Correlates of voluntary blood donation among the people in a hill capital in India. International Journal of Green Pharmacy. 2009:3(2):167-174.

15. Khadir M, Maghsudlu M, Gharehbaghian A, Danandeh E, Faghih H, Vafaiyan V, The evaluation of the attitude of Iranian women towards blood donation. Sci J Iran Blood Transfusion Organ. 2004;1:27-34

16. Palestinina central Bureau of Statistics. Knowledge, Attitudes and Trends of the Palestinian Community about Blood Donation, 2003 http.//www.pcds.gov.ps/Portals_pcds/pressRelease/ blood.pdf

17. Shailesh K Mishra, Suchet Sachdev, Neelam Marwaha and Ajit Avasthi. Study of knowledge and attitude among college going students toward voluntary blood donation from north India. Journal of blood medicine, 2016:19-26. 